\title{
Rbabdocbona praecox sp.n. and Proleptus sp. (Spiruroidea : Nematoda) from fresh water crabs in Ceylon
}

\author{
by George O. POINAR, Jr. ${ }^{1}$ and D. W. W. KANNANGARA ${ }^{2}$
}

Laboratoire de Zoologie (Vers), associé au C.N.R.S. (Pr A.-G. Chabaud), Muséum National d'Histoire Naturelle, 57, rue Cuvier, F. 75 -Paris-5e

\section{Résumé}

Des adultes de Rhabdochona praecox $\mathrm{n}$. $\mathrm{sp}$. et des larves de Proleptus sp. sont récoltés chez des crabes d'eau douce de Ceylan appartenant au genre Paratelphusa (Potamonidae).

L'espèce $R$. praecox se développe complètement dans l'hépatopancréas du crabe, puisque les femelles ont des œufs mûrs, embryonnés. Il paraît vraisemblable que tout le développement se réalise de cette manière, sans nécessiter ultérieurement un hôte vertébré, ce qui traduit un mode d'évolution très spécialisé pour un nématode appartenant à un groupe primitif de spirurides.

Différents caractères morphologiques permettent par ailleurs de distinguer $R$. praecox des autres Rhabdochonidae. Ce sont: la présence de glandes paires situées à côté des papilles céphaliques, la morphologie du spicule filiforme et le nombre réduit de papilles précloacales.

La présence de larves de Proleptus chez un crabe d'eau douce est intéressante à signaler car la plupart des espèces décrites jusqu'à présent ont un habitat marin.

\section{Summary}

Adults of Rhabdochona praecox sp. $\mathrm{n}$. and juveniles of Proleptus sp. were collected and described from Ceylonese freshwater crabs of the genus Paratelphusa (Potamonidae). Not only do the

(1) On leave from the Department of Entomology and Parasitology, University of California, Berkeley, California, 94720.

(2) Department of Parasitology, Faculty of Medicine, Colombo 8, Ceylon. 
adults of $R$. praecox mature in the hepatopancreas of the crab, but mating and egg maturation also occurs in this habitat. It is likely that the entire cycle can be completed in the absence of a vertebrate host, a specialized type of behavior for a nematode belonging to a primitive group of spirurids.

The specialized morphological characters of $R$. praecox, namely the presence of paired glands adjacent to the cephalic papillae, the structure of the filiform spicule and the reduced number of genital papillae, separate this species from othe: rhabdochonids.

The presence of iuvenile Proleptus from a fresh water crab is interesting because the majority of the previously described species are from a marine habitat.

\section{Introduction :}

While making a survey of the parasites of Ceylonese freshwater crabs, the junior author collected adult nematodes from the hepatopancreas of Paratelphusa rugosa (Kingsley) and juvenile nematodes from the hepatopancreas of $P$. ceylonensis Fernando, $P$. innominata Fernando, $P$. soror (Zehntner) and $P$. rugosa.

The latter nematode is probabiy the commonest parasite of Ceylonese fresh water crabs, being especially abundant in ceylonensis and rugosa (Kannangara, in Press). The first record of this parasite was possibly made by Fernando (1960) when he reported : «We also found an unidentified larval nematode in the hepato-pancreas of $P$. ceylonensis ». Nematodes collected from the crabs were sent to the senior author for determination. The adult nematodes proved to be a new species of Rhabdochona and the juveniles belonged to the genus Proleptus. A description of both forms is given below and the biological significance of these finds is discussed.

\section{Material and methods :}

Fresh water crabs were coliected from various localities in Ceylon from October 1968 to March 1970 . The crabs were first paralysed by destroying the ventral ganglionic mass, then the carapace was opened and the nematode parasites were removed from the hepatopancreas and placed into a saline solution. They were then fixed in $70 \%$ alcohol and processed to glycerin.

\section{Results :}

In the quantitative portion of the following descriptions, the number following the character represents the average value for that character while the numbers in parenthesis show the range of that character. All measurements are given in microns unless otherwise specified. 


\section{Rbabdocbona praecox sp. nov. (fig. 1 et 2)}

Spirurida, Spiruroidea, Thelaziidae, Railliet, 1916, Rhabdochona Railliet, 1916.

Cuticle thin, about 6 microns in thickness, smooth, without ornamentations; lips indistinct, with an inner and outer circle of 4 cephalic papiliae. Each outer papilla is bordered by a pair of cup-shaped glands, which are covered by a swollen portion of the cuticle; mouth opsning slightiy hexagonal, leading into a weli defined stoma which is cylindrical at the base, but funnel shaped at the anterior portion; a small esophageal collar, 18 microns long, surrounds the base of the stoma and eight teeth surround the mouth opening; muscuiar and glandular portions of the esophagus unequal, with a small valve at the base of the latter portion; deirids and phasmids inconspicuous.

Female $(\mathrm{n}=10)$ : length, 27 (17-57) mm; width, 197 (153-315); diameter of mouth opening, 18 (16-21); length of testh, 7 (7-9); length of stoma, 200 (162-234); length of muscular portion of esophagus, 266 (207-315); length of glandular portion of esophagus, 515 (432-738); length of head to nerve ring, 218 (135-270); length of head to excretory pore, $359(279-472)$; vulva, $57(52-71) \%$ from head end; length of vagina, 1.3i (.611.71) $\mathrm{mm}$; ovaries paired, opposite, reflexed or extended at tip, the posterior one sometimes extending to the anus; eggs (embryonated) not filamented or bearing floats, thin walled, $29(25-35) \times 17(14-23)$; tail pointed, 413 (279-540) long.

MAle ( $\mathrm{n}=10)$ : length, $10(7-13) \mathrm{mm}$; width, 127 (99-144); diameter of mouth opening, 16 (14-18) ; length of teeth, 7 (7-9) ; length of stoma, 173 (135-189) ; length muscular portion of esophagus, 203 (135-261); length glandular portion of esophagus, 401 (351-522); length head to nerve ring, 215 (176-243); length head to excretory pore, 318 (252-387) ; testis single, reflexed at tip; left spicule long, filiform, the ventral shaft terminating in a fine point, $2.1(1.7-2.5) \mathrm{mm}$ long; right spicule short, wide, with a membrane-like plug at the tip, 86 (71-97) long; leng:h of gubernaculum-like structure, 38 (28-46) ; length tail, 373 (274-522) ; bursa lacking, caudal fapillae reduced in number, 3 pairs of post-anal papillae and 2 pairs of preanal papillae.

TYPE SPECIMENS: deposited at the Museum National d'Histoire Naturelle, Laboratoire de Zoologie (Vers), 43, rue Cuvier, Paris-V ${ }^{*}$. Slide N, II-87, 88.

Host : In the hepatopancreas of the fresh water crab, Paratelphusa rugosa (Kingsley) Potamonidae (fig. 3).

LOCALITY: Rapidly flowing mountain streams at Upper Hantane and Nuwara-EliyaGampola Road (Central Province) and Madulusima, Weraya and Lunugala-Bibile Road (Uva Province) in Ceylon.

Diagnosis. $R$. praecox can be easily distinguished from all previously described species of Rhabdochona by the large size of the female the proportionally small esophagus (especially the Plandular portion), the p:e:ence of paired cup-shaped structures flanking the cephalic papillae, the extreme length of the filiform left spicule, the reduced number of preanal caudal papillae and the straight stoma with a gradual widening at the top. Previous 


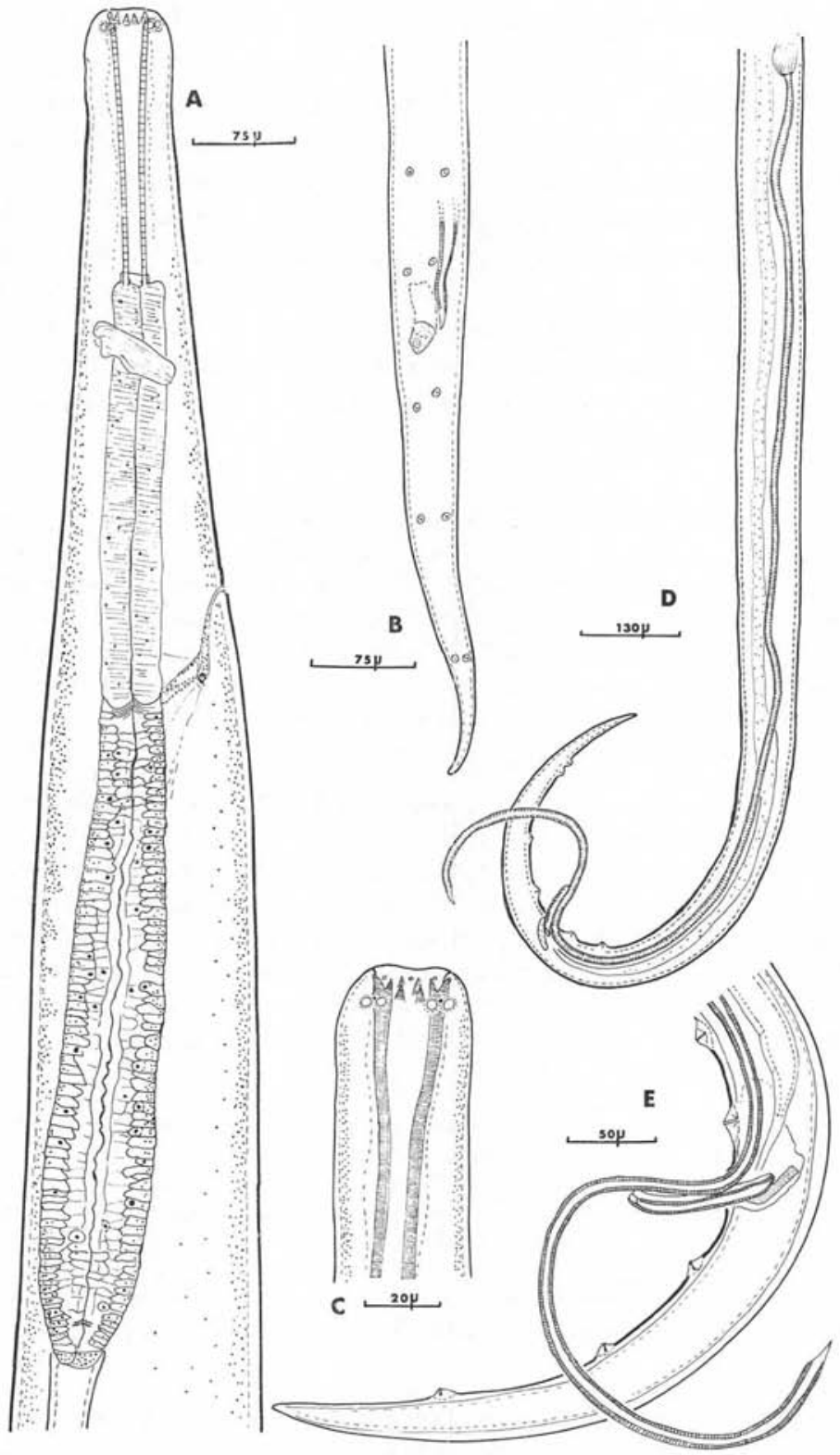

FIG. 1. - Rhabdochona praecox sp. n. A. Dorsal view of anterior region of female. B. Ventral view of male tail. C. Dorsal view of male head. D. Lateral view of posterior region of male. E. Lateral view of male tail 

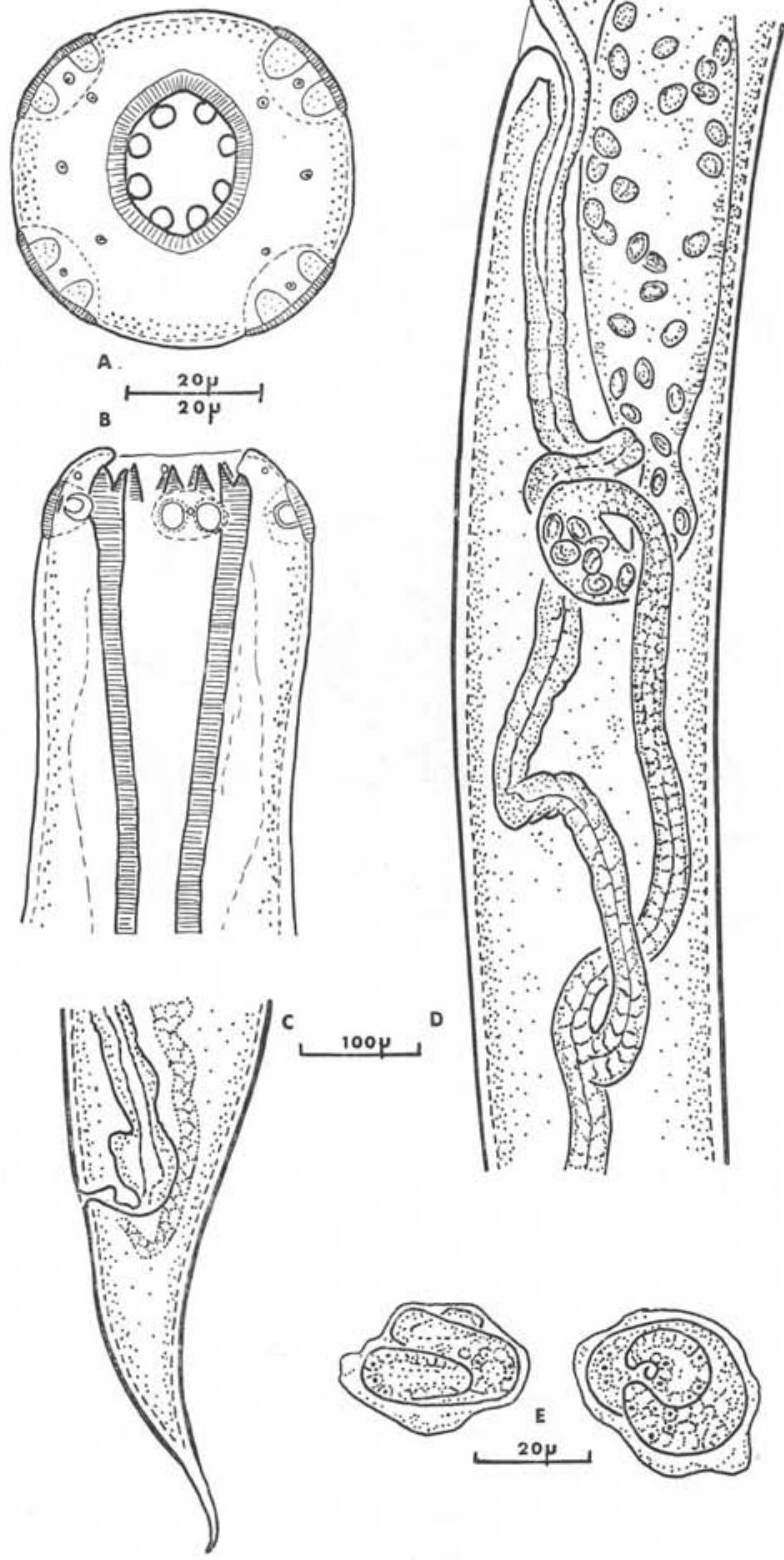

FIG. 2. - Rhabdochona praecox sp. n. A. «En face» view of female. B. Ventral view of fema!e head. C. Lateral view of female tail. D. Lateral view of vuiva and vagina. F. Eggs removed from uterus of female 
workers have characterized the genus Rhabdochona and discussed some of the variability in the generic characters (Campana-Rouget, 1953, Rasheed, 1965). A gubernaculum was previously reported only for $R$. (Filochona) ovifilamenta Weller (1938) and is rare in this genus. In $R$. praecox, this structure is not sclerotized and until the ontogeny is known, it is perhaps better to consider it as a « gubərnaculum-like » structure. It supports the right spicule which is shortened and in turn performs the function of a normal gubernaculum by supporting the filiform left spicule. The unique cup-like structures surrounding the cephalic papillae appear to be filled with a homogeneous material and are probably chemicalsensory in nature.

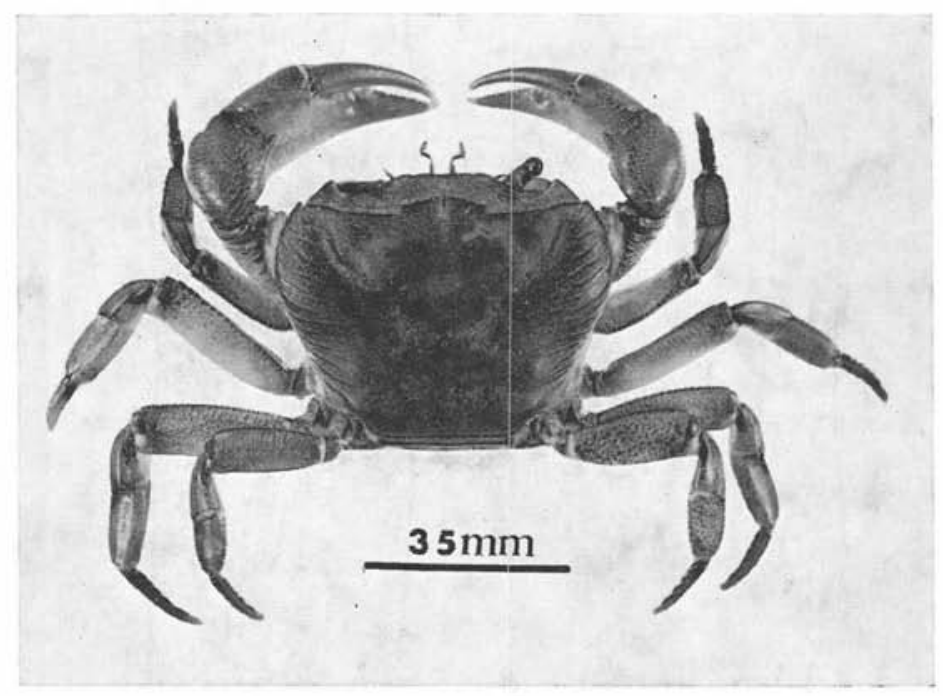

Fig. 3. - Paratelphusa rugosa (Kings'ey)

\section{Biology :}

Early larval development of rhabdochonids is known to occur in mayflies (Hexagenia sp.) (Gustafson, 1942) and possibly, in the crustacean, Hyalella knickerbockeri in the case of $R$. ovifilamenta (Weller, 1938). However, this is the first species of Rhabdochona known to mature to the adult stage in the body cavity of a crab. Under certain conditions, some rhabdochonid 3 are able to develop to the adult stage in the invertebrate host. Fully developed males and females of $R$. cascadilla Gustafson were found in nymphs of the mayfly Hexagenia (Gustafson, 1942). Although the females contained unfertilized ova, all characters agreed with the adult description based on material obtained from the determinate host.

With $R$. praecox, not only do the nematode develop to the adult stage in the crab, but mating and egg maturation also occurs in the invertebrate host. 
It therefore appears that $R$. praecox has modified its behavior for completing its development in the crab and the vertebrate host has either dropped out of the cycle or functions as a facultative host.

The discovery of a rhabdochonid nematode which matures in the body cavity of an invertebrate poses an interesting question regarding the evolution of this species and other lines of spirurid nematodes. Did the spirurids originate in vertebrate or invertebrate hosts? Regarding $R$. praecox, if the former hypothesis is correct, one might expect to find a morphologically specialized form in the invertebrate host. If however, the latter hypothesis is correct, the presence of a morphologically primitive type would be expected in the invertebrate host. $R$. praecox possesses some rather specialized morphological features in comparison to the other species in this genus, namely, the long filiform left spicule, the reduced number of genital papillae, the paired glands adjacent to the cephalic papillae, and the straight walls of the stoma.

Thus, we suggest that $R$. praecox initially evolved with a vertebrate host which either became lost or reduced in numbers as a result of a change in ecological conditions and the nematode then achieved the ability to complete its development in the invertebrate host, in this case, a crab.

\section{Proleptus sp. (fig. 4)}

Although the determinate host of the Proleptus found in P. rugosa and P. ceylonensis was not recovered, and thus the adult specimens are wanting, a description of the juvenile stages in the crab will be given because of their abundance and the interesting discovery of a Proleptus in a fresh waer intermediate host. All the nematodes were taken from the hepatopancreas of the crab and appear morphologically to be at the same stage of development (presumably the third stage).

Spirurida. Physalopteridae (Railliet, 1893). Proleptus sp.

Cuticle annulated and expanded into a cephalic cord that encircles the neck region; head bearing 2 pseudolips, each with a single lateral « tooth-papilla ». Four other submedian papillae complete the inner labial circle. The outer labial circle is composed of 4 papillae, and 2 amphids. The mouth opening and stoma are laterally compressed ; a pair of deirids is visable just anterior to the nerve ring.

Quantitative measurements $(\mathrm{n}=10)$ : length, $29(22-35) \mathrm{mm}$; greatest width, 450 (330-660) ; width of head, 110 (90-130) ; length stoma, 50 (40-60); length muscular esophagus, 560 (450-620); length glandular esophagus, 353 (264-409); head to nerve ring, 320 (260-360); head to excretory pore, 490 (420-560); length of tail, 100 (90-130), rounded with sometimes a small mucron at the tip.

Host AND LOCality Records: The Proleptus species was collected from the hepatopancreas of Paratelphusa rugosa from Uva, Sabaragamuwa, Central and Western provinces, from $P$. ceylonensis from Uva, Sabaragamuwa, North Central, Central and North Western, 


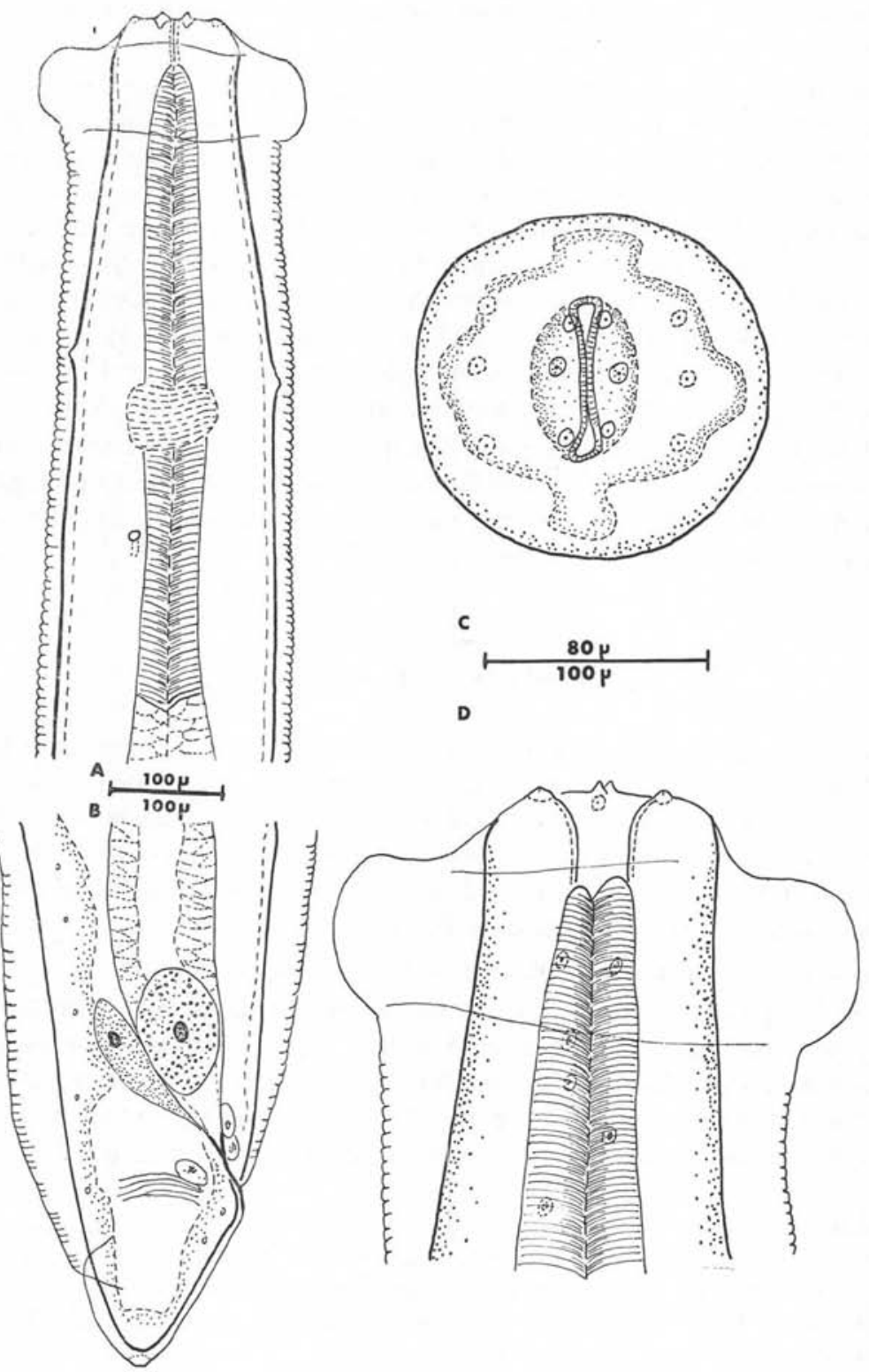

FIG. 4. - Juvenile Proleptus sp. A. Ventral view of anterior portion. B. Lateral view of tail. C. «En face » view. D. Lateral view of head region 
Western and Eastern provinces, from $P$. innominata from the Northern province and from $P$. sorror from the Sabaragamuwa province, all in Ceylon. A more precise list of host localities is given by Kannangara (In press).

Kannangara (In press) also reported that frogs can serve as transitory hosts to the species of Proleptus. Some growth occured in the frog, but the nematodes were then voided in about 1 week.

The great majority of the described species of Proleptus are marine, with sharks and rays serving as the determinate host. Pearse (1933) described Proleptus anabantis from the air breathing fish, Anabor testudineus, a fresh water estuarine form. Aside from the Proleptus juvenile described here, this report represents the only case of a Proleptus from a non-marine habitat.

\section{ACKNOWLEDGEMENTS}

The senior author is indebted to Dr. A. G. Chabaud and J.-C. Quentin for laboratory space and special council during this study.

The junior author wishes to thank Prof. A.S. Dissanaike, in whose lobaratory the examinations were made, and Mr. G. M.S. Karunaratne, who assisted in collecting and dissecting the crabs.

\section{Bibliography}

Campana-Rouget (Y.), 1955. - Sur deux nouveaux genres de spirurides parasites; discussion systématique des genres voisins. Ann. Parasit. Hum. Comp., 30, 346-362,

Fernando (C. H.), 1960. - The Ceylonese freshwater crabs (Potamonidae). Ceylon J. Sci., 3, 191-222.

Gustavson (P. V.), 1942. - A peculiar larval developmen: of Rabdochona spp. (Nematoda: Spiruroidea). J. Parasit., 28, (suppl.), 30.

Kannangara (D. W. W.), 1971. - On some aspects of the parasites of Ceylonese fresh water crabs. Ceylon J. Sci. (in press).

Pearse (A. S.), 1933. - Parasites of Siamese fishes and crustaceans. J. Siam, Soc, Nat, Hist., Supp., 9, 179-191.

RASHEED (S.), 1965. - A preliminary review of the genus Rhabdochona Railliet, 1916 with description of a new and related genus. Acta Parasit. Polonica, 13, 407-424.

Weller (T. H.), 1938. - Description of Rhabdochona ovifilamenta n.sp. (Nematoda: Thelaziidae) with a note on the life history. J. Parasit., 24, 403-408. 